\title{
ANAEMIA OF FELTY'S SYNDROME
}

\author{
BY \\ R. HUME, J. H. DAGG, T. N. FRASER, AND A. GOLDBERG \\ University Department of Medicine, Gardiner Institute, and Western Infirmary, Glasgow
}

Since Felty's description in 1924 of a syndrome consisting of chronic arthritis, splenomegaly, and leucopenia, there has been much speculation on its essential nature. The condition has been considered to be an unusual variant of rheumatoid arthritis (Hutt, Richardson, and Staffurth, 1951) or simply the fortuitous association of chronic arthritis and cirrhosis of the liver with portal hypertension (Felty, 1924; Cudkowicz, 1956; Layani, Durupt and Amor, 1959). The leucopenia associated with splenomegaly has been explained on the concept of hypersplenism (Doan and Wright, 1946; Evans, Takahashi, Duane, Payne and Liu, 1951; Hutchison and Alexander, 1954; Dameshek, 1955). Less attention has been paid to the investigation of the anaemia which commonly occurs. It is of interest that each of the patients described by Felty had a haemoglobin of approximately $10 \mathrm{~g}$. per cent. and that urobilin was detected in the urine of one patient; in many instances when splenectomy was performed there was a marked improvement in the anaemia as well as relief of the leucopenia (Smith and McCabe, 1948; Hutt and others, 1951; Hutchison and Alexander, 1954), but not in every case (Hutt and others, 1951; Cudkowicz, 1956). In this paper we have studied the mechanism of this anaemia both before and after splenectomy in four patients with Felty's syndrome.

\section{Material and Methods}

\section{Radioisotopic Techniques}

Radiochromium $\left({ }^{51} \mathrm{Cr}\right)$. The radiochromium technique was based on the method of Mollison and Veall (1955). The red cells from $20 \mathrm{ml}$. of the patient's blood were labelled with $100 \mu \mathrm{c}$. ${ }^{51} \mathrm{Cr}$ (sodium chromate) and administered intravenously; acid citrate dextrose was used as the anticoagulant. This gave a measure of the red cell half life $\left({ }^{51} \mathrm{Cr} \mathrm{T} \frac{1}{2}\right)$ for each patient and thus of the degree of haemolysis. The mean ${ }^{51} \mathrm{Cr} \mathrm{T} \frac{1}{2}$ in six haematologically normal patients was $28 \pm 5$ (S.D.), range 22-35 days, which is in agreement with the findings observed by other workers (Berlin, Waldmann and Weissman, 1959). In order to determine whether or not the spleen was acting as an organ of erythrocyte sequestration, radioactivity was also measured by surface counting over the heart, liver, and spleen as described by Jandl, Greenberg, Yonemoto, and Castle (1956). A spleen/liver ratio at $T_{\frac{1}{2}}$ of at least $2 \cdot 3$ to 1 was considered to be evidence of splenic sequestration of a degree sufficient to suggest that splenectomy would relieve a haemolytic anaemia (Goldberg, 1960).

Radioiron $\left({ }^{59} \mathrm{Fe}\right) .-10 \mu \mathrm{c}$. radioactive iron in the form of ferric chloride was injected intravenously into one patient. The rate of plasma clearance was estimated and changes in radioactivity were recorded at intervals over the heart, spleen, liver, and sacrum (Ledlie and Baxter, 1954) over a period of 100 hours. The sacrum was used as a convenient site for recording bone marrow activity. A sample of blood was removed at 14 days after the radioiron administration in order to determine the utilization of the injected iron for haemoglobin formation. The normal utilization of radioiron under these conditions is 68 to 83 per cent. (Finch, Gibson, Peacock, and Fluharty, 1949). The blood volume was measured by the technique described by Muldowney (1957) using the dye dilution method (Evans blue). Routine haematological measurements were made according to Dacie (1956).

\section{Histopathology}

Sections of the spleen and of a liver biopsy taken during operation were examined in each case; special stains were applied to demonstrate the presence of haemosiderin (Prussian blue reaction), reticulum network (Fontana) and in the liver specimens, fibrous tissue (van Gieson).

\section{Clinical Data}

Case 1, a 66-year-old housewife, was first seen in December, 1960. She had suffered from rheumatoid arthritis for 15 years. Her hands, ankles, feet, and knees showed typical deformities with characteristic radiological changes. The sheep cell agglutination test was positive. In recent years she had developed dyspnoea on exertion and loss of weight; her spleen had become palpable 2 in. below the costal margin. Routine haematological investigation revealed anaemia, thrombocytopenia, and leucopenia (Table I, overleaf). Examination of the bone marrow showed increased cellularity of both red and white cell series with maturation arrest of the granular cells, i.e. appearances characteristic of hypersplenism (Table III, overleaf). Radiochromium studies demonstrated a haemolytic anaemia with evidence of splenic sequestration (Table II, overleaf).

Splenectomy was advised, but the patient refused operation. 9 months later she was readmitted with 
TABLE I

RESULTS OF BLOOD INVESTIGATIONS BEFORE AND AFTER SPLENECTOMY

\begin{tabular}{|c|c|c|c|c|c|c|c|c|}
\hline \multirow{2}{*}{ Case No. } & \multicolumn{2}{|c|}{ Haemoglobin (g. per cent.) } & \multicolumn{2}{|c|}{ Reticulocytes per cent. } & \multicolumn{2}{|c|}{ Leucocyte Count (per c.mm.) } & \multicolumn{2}{|c|}{ Platelets (103/c.mm.) } \\
\hline & Before & After & Before & After & Before & After & Before & After \\
\hline 1 & $8 \cdot 6$ & $13 \cdot 3$ & $4 \cdot 5$ & 2 & 700 & 6,800 & 95 & 205 \\
\hline 2 & $10 \cdot 7$ & $13 \cdot 5$ & $6 \cdot 5$ & 2 & 880 & 10,000 & 130 & 535 \\
\hline 3 & $8 \cdot 6$ & $14 \cdot 9$ & 14 & 2 & 2,500 & 9,200 & 140 & 210 \\
\hline
\end{tabular}

TABLE II

RADIOISOTOPIC STUDIES BEFORE AND AFTER SPLENECTOMY

\begin{tabular}{|c|c|c|c|c|c|}
\hline \multirow{2}{*}{ Case No. } & \multicolumn{3}{|c|}{ Radiochromium ( ${ }^{51} \mathrm{Cr}$ ) } & \multicolumn{2}{|c|}{ Radioiron ( $\left.{ }^{59} \mathrm{Fe}\right)$ (per cent. utilization) } \\
\hline & $T_{\frac{1}{2}}$ (days) (Before) & $\begin{array}{l}\text { Spleen/Liver } \\
\text { Ratio at } T_{\frac{1}{2}}\end{array}$ & $T_{\frac{1}{2}}$ (days) (After) & (Before) & (After) \\
\hline 1 & 19 & $2 \cdot 3 / 1$ & 39 & - & - \\
\hline 2 & 15 & $2 \cdot 1 / 1$ & 25 & - & - \\
\hline 3 & $5 \frac{1}{2}$ & $2 \cdot 7 / 1$ & 18 & 一 & - \\
\hline 4 & $7 \frac{1}{2}$ & $2 \cdot 8 / 1$ & 29 & 64 & 58 \\
\hline
\end{tabular}

\begin{tabular}{|c|c|c|}
\hline Case No. & Before Splenectomy & After Splenectomy \\
\hline 1 & $\begin{array}{l}\text { Increased cellularity of both red and white cell series } \\
\text { Maturation arrest of granular cells } \\
\text { Megakaryocytes quite numerous } \\
\text { Stainable iron absent }\end{array}$ & $\begin{array}{l}\text { Cellularity normal } \\
\text { Normoblastic erythropoiesis } \\
\text { No maturation arrest of granular cells } \\
\text { Stainable iron present }\end{array}$ \\
\hline 2 & $\begin{array}{l}\text { Normoblastic hyperplasia with maturation arrest of } \\
\text { granulocyte series } \\
\text { Stainable iron absent }\end{array}$ & $\begin{array}{l}\text { Normal cellularity } \\
\text { Normal maturation of neutrophils } \\
\text { Stainable iron absent }\end{array}$ \\
\hline 3 & $\begin{array}{l}\text { Normoblastic hyperplasia } \\
\text { Scarcity of segmented polymorphonuclear leucocytes } \\
\text { Stainable iron absent }\end{array}$ & $\begin{array}{l}\text { Normal cellularity } \\
\text { Normoblastic erythropoiesis, maturation arrest of } \\
\text { granulocytes not seen } \\
\text { Stainable iron absent }\end{array}$ \\
\hline 4 & $\begin{array}{l}\text { Hypercellularity of both red and white cell series } \\
\text { especially the latter } \\
\text { Maturation arrest of granular series } \\
\text { Numerous megakaryocytes } \\
\text { Stainable iron absent }\end{array}$ & $\begin{array}{l}\text { Normal cellularity } \\
\text { Maturation of white cells normal } \\
\text { Stainable iron absent }\end{array}$ \\
\hline
\end{tabular}

vomiting, abdominal colic, and diarrhoea. The spleen was now $6 \frac{1}{2}$ in. below the costal margin and the liver was palpable. The blood levels were virtually unchanged. After treatment for a finger-pulp infection, splenectomy was carried out in November, 1961. During the operation excessive capillary oozing was noted. Thereafter the platelet count and the white cell count returned to normal figures within 2 and 14 days respectively. The haemoglobin level gradually rose to reach $14.8 \mathrm{~g}$. per cent. after 6 months (Table I). The blood levels have remained normal during the past 2 years and her general condition has improved.

Case 2, a 62-year-old housewife, was first seen in April, 1959 , when she gave an 8-years' history typical of rheumatoid arthritis involving hands, elbows, shoulders, knees, ankles, and feet. Conjunctivitis, blepharitis, and frequent chest infections had occurred intermittently for
4 years. She had complained of general weakness and malaise for several months. She was a thin, wasted woman with pallor of the skin. Small discrete glands were palpable in neck and axillae. There was a patch of ecchymosis on the right forearm. The spleen was palpable 3 in. below the costal margin. The sheep cell agglutination test was weakly positive. Haematological investigations revealed a moderate anaemia associated with reticulocytosis, leucopenia, and thrombocytopenia (Table I). The marrow histology was again typical of hypersplenism (Table III). The urinary urobilinogen ranged between 2.8 and $11 \mathrm{mg} . / 24$ hours. Radiochromium studies confirmed the presence of a haemolytic anaemia with a spleen/liver ratio at $T \frac{1}{2}$ of $2 \cdot 1$ to 1 (Table II). Prednisolone $60 \mathrm{mg}$. per day, commenced in May, 1959, resulted in symptomatic improvement of the arthritis with relief of the conjunctivitis. The haemoglobin rose to normal with a fall in the reticulocytes to 3 per cent. The white cell count also increased to normal 
levels. The prednisolone was gradually reduced to 10 mg. per day by June, 1959. Thereafter the haemoglobin and the white cell count began to fall and there was recurrence of conjunctivitis. Splenectomy was, therefore, performed in August, 1959. Within 24 hours the white cell count and platelet count had returned to normal. Over the next 3 months the haemoglobin slowly returned to normal. Prednisolone $10 \mathrm{mg}$./day was continued because of persistence of joint pains. During the ensuing year, respiratory infections and conjunctivitis were less troublesome. Repeat radiochromium studies showed an improvement in erythrocyte survival from ${ }^{51} \mathrm{Cr} \mathrm{T} \frac{1}{2}$ of 15 to 25 days (Table II). This patient died 3 years later from chronic pyelonephritis and uraemia.

Case 3, a 52-year-old woman clerk, was first seen in December, 1938, when she gave a 15-months' history of polyarthritis involving the knees, wrists, fingers, and temporo-mandibular joints. Clinical and $x$-ray appearances were typical of rheumatoid arthritis. The patient was eventually discharged in March, 1941, when the arthritis was much improved and considered to be in remission. Between 1943 and 1947 the patient underwent a number of orthopaedic operations because of deformity, disability, and destruction of the joints in the feet and left wrist. This produced a greater degree of mobility. In 1959 she presented with jaundice (serum bilirubin $4.0 \mathrm{mg}$. $/ 100 \mathrm{ml}$.) and splenic enlargement 1 in. below the costal margin. Blood examination showed anaemia, reticulocytosis, and leucopenia. The platelet count was normal (Table I). Marrow histology was compatible with hypersplenism (Table III). The Coombs test was positive. The sheep cell agglutination and L.E.-cell tests were negative. Radiochromium studies confirmed a severe haemolytic anaemia, ${ }^{51} \mathrm{Cr} \mathrm{T} \frac{1}{2}$ of 5 days, with evidence of splenic sequestration (spleen/liver ratio at $\mathrm{T}_{2}^{\frac{1}{2}}$ of $2 \cdot 7$ to 1) (Table II). Splenectomy was carried out in December, 1959. Within 4 days the white cell count had increased to $22,000 / \mathrm{cmm}$., later falling to normal levels. The haemoglobin reached normal levels $2 \frac{1}{2}$ months later. Repeat red cell survival studies 4 months after the operation showed an improvement in the ${ }^{51} \mathrm{Cr} \mathrm{T} \frac{1}{2}$ to 18 days.

In spite of general improvement, the patient continued to be troubled with joint pains, and prednisolone 10 mg./day was commenced in April, 1960. Since then she has remained reasonably well although considerably restricted in her movements. Her blood picture has remained normal.

Case 4, a 45-year-old housewife, was admitted to hospital in February, 1962, with acute abdominal pain. For 15 years she had suffered from polyarthritis, severe enough to warrant two previous admissions. On this occasion she was found to have an enlarged spleen $4 \frac{1}{2}$ in. below the costal margin and an enlarged liver 2 in. below the costal margin. The pain was attributed to splenic infarction. There were severe joint deformities characteristic of rheumatoid arthritis involving the hands, elbows, hips, knees, ankles, and feet. Palmar erythema was noted with spider naevi present on arms and face; there was also pigmentation of the legs. In addition there was clinical and radiological evidence of mitral stenosis, but without any previous history of rheumatic fever or streptococcal infection. There was a marked anaemia, leucopenia, and thrombocytopenia (Table I). Marrow histology was characteristic of hypersplenism (Table III). The sheep cell agglutination and L.E.-cell tests were both positive. Serum bilirubin was not raised. The serum globulin and the routine sero-flocculation tests of liver function were increased. The bromsulphthalein test showed a 23 per cent. retention at 1 hour. Radiochromium studies revealed a severe haemolytic anaemia with evidence of splenic sequestration (Table II). The percentage radioiron $\left({ }^{59} \mathrm{Fe}\right)$ utilization at 14 days was just outside the lower limit of normal (Table II). The radioiron profile obtained by surface counting over sacrum, heart, liver, and spleen was normal, and the plasma iron turnover was also normal $(0.49 \mathrm{mg}$. $/ 100 \mathrm{ml}$.) $24 \mathrm{hrs}$ ). Splenectomy was performed in April, 1962. Within 4 days of the operation the white cell count and platelet count had risen to normal. The haemoglobin reached normal levels 5 months later. Repeat radioisotopic studies 7 months after operation showed no significant change in the radioiron utilization (58 per cent.) or in the plasma iron turnover $(0.59 \mathrm{mg} . / 100$ $\mathrm{ml} . / 24 \mathrm{hrs}$ ), while the ${ }^{51} \mathrm{Cr} \mathrm{T} \frac{1}{2}$ rose from $7 \cdot 5$ to 29 days. The polyarthritis was unchanged. The haematological state has remained normal for 18 months.

\section{Discussion}

The four patients in the present study are, by definition, cases of Felty's syndrome. The condition described by Felty (1924) comprised a triad of chronic arthritis in the adult associated with splenomegaly and leucopenia. At that time no serological methods were available for the more precise definition of rheumatoid arthritis. Felty considered the condition to be similar to Still's disease of children. Robinson (1963) has noted that in rheumatoid arthritis lymphadenopathy occurs occasionally and splenomegaly is found in 5 to 10 per cent. of cases. It is likely that Felty's syndrome occurs within this group of patients in whom the enlargement of the spleen has for some unknown reason been also associated with "hypersplenism".

On the other hand, Layani and others (1959) argued that it is merely the fortuitous association of chronic arthritis and liver disease with portal hypertension. In the present series two patients (Cases 1 and 2) have unequivocal rheumatoid arthritis (Ropes, Bennett, Cobb, Jacox, and Jessar, 1959). Case 3 has a negative sheep cell agglutination test although she had the typical joint deformities and radiological appearances of rheumatoid arthritis. Case 4 had mitral valve disease, histological evidence of a low grade hepatitis (Table IV), and positive sheep cell agglutination and L.E.-cell tests. This patient may have disseminated erythematosus. 
In Cases 1, 2, and 3 the liver was normal or showed only minor changes (Table IV).

In Felty's original description, each of his cases had a haemoglobin of approximately $10 \mathrm{~g}$. per cent. In most cases in which splenectomy was performed, there was a marked improvement in the anaemia (Cudkowicz, 1956). In uncomplicated rheumatoid arthritis, especially during the active phase of the disease, there is usually an associated moderate normochromic normocytic anaemia. The mechanism of this anaemia has been investigated by several workers. Bunim (1954) was the first to show that there was a shortening of the red cell survival time. This was subsequently confirmed by Ebaugh, Peterson, Rodnan, and Bunim (1959) and Weinstein (1959). Richmond, Alexander, Potter, and Duthie (1961) drew attention to the fact that the haemolytic process was of the extracorpuscular type, that it was mild in degree and more readily demonstrable by injecting labelled donor cells than by labelling the patient's own cells. In Weinstein's series the most active haemolytic process was associated with splenomegaly in two patients. Each of the four patients in the present series had a shortened red cell survival time, the ${ }^{51} \mathrm{Cr} \mathrm{T} \frac{1}{2}$ 's ranging from $5 \cdot 5$ to 19 days (normal $28 \pm 5$ ) and Case 3 had red cell antibodies demonstrable by the Coombs test. Surface counting over the liver and spleen revealed that in Cases 1, 3, and 4 the spleen/liver ratio was greater than $2 \cdot 3: 1$. In Case 2 , although the splenic sequestration studies did not alone indicate that splenectomy would be beneficial, the profound leucopenia and repeated infections justified this procedure. A satisfactory haematological response occurred in each case; the red cell survival returned to normal ( $28 \pm 5$ days) in Cases 1,2 , and 4 and from $5 \frac{1}{2}$ to 18 days in Case 3.

Hypersplenism is clearly the important factor which is responsible for the haematological differences between Felty's syndrome and uncomplicated rheumatoid arthritis. Hypersplenism has been applied to that state in which some or all of the formed elements of the blood are depressed as a result of the influence of the spleen. The strongest evidence for the role of the spleen in these conditions has been the prompt relief of the clinical and haematological picture following splenectomy. The mechanism by which the spleen exerts its influence is of interest. Doan and Wright (1946) suggested that there was selective sequestration of the various blood elements in the spleen with their eventual phagocytosis and destruction. Dameshek (1955) favoured a humoral mechanism whereby the spleen had an indirect action upon the bone marrow, either preventing the growth or maturation of the various cells, or blocking their delivery from the marrow to the blood. Finally, it was considered that many cases were attributable to the formation of autoantibodies to blood cells by the reticulo-endothelial tissues including the spleen and with destruction of the sensitized cells in the spleen (Evans and others, 1951). Whatever the mechanism of hypersplenism may be, in each patient of the present study there was complete restoration of the bone marrow to normal after splenectomy. The radiochromium studies and the histology of the spleens (Table IV) support the view that selective sequestration occurs in the spleen.

Although haemolysis appears to have been the major factor in the production of the anaemia in

TABLE IV

HISTOLOGICAL FINDINGS IN LIVER AND SPLEEN

\begin{tabular}{|c|c|c|c|c|}
\hline Case & 1 & 2 & 3 & 4 \\
\hline $\begin{array}{l}\text { Liver } \\
\text { Biopsy }\end{array}$ & $\begin{array}{l}\text { Some foci of liver cell atrophy } \\
\text { and others of hyperplasia } \\
\text { Excessive iron in Kupffer cells } \\
\text { No fibrosis seen }\end{array}$ & $\begin{array}{l}\text { Moderate fatty infiltration, } \\
\text { mainly centrilobular in } \\
\text { position }\end{array}$ & Normal & $\begin{array}{l}\text { Low grade hepatitis with } \\
\text { marked focal hyperplasia } \\
\text { and atrophy with chronic } \\
\text { inflammatory cell infiltrate } \\
\text { Some thickening of reticulum } \\
\text { network and increase in } \\
\text { fibrous tissue } \\
\text { Excessive iron in some Kupffer } \\
\text { cells }\end{array}$ \\
\hline Spleen & $\begin{array}{l}\text { Weight } 1150 \mathrm{~g} . \\
\text { Sinusoids dilated } \\
\text { Malpighian corpuscles en- } \\
\text { larged with active germ } \\
\text { centres } \\
\text { Red pulp congested with } \\
\text { evidence of erythrophago- } \\
\text { cytosis, excess plasma cells, } \\
\text { and extramedullary } \\
\text { haemopoiesis } \\
\text { Reticulum network normal } \\
\text { Excessive iron in reticulum } \\
\text { cells }\end{array}$ & $\begin{array}{l}\text { Weight } 500 \mathrm{~g} . \\
\text { Sinusoids dilated } \\
\text { Malpighian corpuscles normal } \\
\text { Excessive plasma cells in pulp } \\
\text { and evidence seen of extra- } \\
\text { medullary haemopoiesis and } \\
\text { erythrophagocytosis } \\
\text { Reticulum cells diminished } \\
\text { Reticulum not increased }\end{array}$ & $\begin{array}{l}\text { Weight } 400 \mathrm{~g} . \\
\text { Sinusoids dilated } \\
\text { Malpighian corpuscles } \\
\text { large, a few showing } \\
\text { germ centres } \\
\text { Pulp and reticulum } \\
\text { normal } \\
\text { No excess iron } \\
\text { deposition }\end{array}$ & $\begin{array}{l}\text { Weight } 1500 \mathrm{~g} \text {. } \\
\text { Sinusoids dilated } \\
\text { Malpighian corpuscles hyper- } \\
\text { plastic with prominent germ } \\
\text { centres } \\
\text { Red pulp congested and } \\
\text { erythrophagocytosis and } \\
\text { extramedullary haemopoiesis } \\
\text { present } \\
\text { Reticulum cells contain } \\
\text { excessive iron } \\
\text { Reticulum not increased }\end{array}$ \\
\hline
\end{tabular}


these four patients, in uncomplicated rheumatoid arthritis it is not the chief factor. There is evidence that in rheumatoid arthritis there is impaired haemoglobin synthesis (Weinstein, 1959). Iron utilization studies carried out before and after splenectomy in Case 4 in the present series showed evidence of impaired haemoglobin production. These results, particularly before splenectomy when there was a profound haemolytic anaemia, emphasizes the inadequate compensatory marrow-response.

Splenectomy, in the present series, also corrected the leucopenia in each case and the thrombocytopenia which occurred in two patients. There was a decided improvement in the well-being of all patients and the recurrent infections present in two patients ceased.

\section{Summary}

The mechanism of the anaemia in four cases of Felty's syndrome was studied, using radioactive chromium $\left({ }^{51} \mathrm{Cr}\right)$ as a red cell label before and after splenectomy. In one case iron utilization was also measured, using radioactive iron $\left({ }^{59} \mathrm{Fe}\right)$ before and after splenectomy. It was concluded that the anaemia is mainly due to haemolysis. There was evidence of increased splenic sequestration of erythrocytes and the anaemia was rectified in all patients by splenectomy. Radioiron studies confirmed an inadequate iron utilization for haemoglobin synthesis and this was not improved by splenectomy. Splenectomy corrected the leucopenia present in each case and also the thrombocytopenia which occurred in two of them.

Our thanks are due to Dr. J. R. Anderson for the histopathological reports.

\section{REFERENCES}

Berlin, N. I., Waldmann, T. A., and Weissman, S. M. (1959). Physiol. Rev., 39, 577.

Bunim, J. J. (1954). Ann. rheum. Dis., 13, 365. Cudkowicz, L. (1956). R Reumatism, 12, 37.

Dacie, J. V. (1956). "Practical Haemotology," 2nd ed. Churchill, London.

Dameshek, W. (1955). Bull. N. Y. Acad.Med., 31, 113.

Doan, C. A., and Wright, C. S. (1946). Blood, 1, 10.

Ebaugh, F. G., Peterson, R. E., Rodnan, G. P., and Bunim, J. J. (1955). Med. clin. N. Amer., 39, 489.

Evans, R. S., Takahashi, K., Duane, R. T., Payne, R., and Liu, C. (1951). Arch. intern. Med., 87, 48.

Felty, A. R. (1924). Bull. Johns Hopk. Hosp., 35, 16.

Finch, C. A., Gibson, J. G., Peacock, W. C., and Fluharty, R. G. (1949). Blood, 4, 905.
Goldberg, A. (1960). Quart.J. Med., 29, 637.

Hutchison, H. E., and Alexander, W. D. (1954). Blood, 9,986.

Hutt, M. S. R., Richardson, J. S., and Staffurth, J. S. (1951). Quart.J. Med., N.S. 20, 57.

Jandl, J. H., Greenberg, M. S., Yonemoto, R. H., and Castle, W. B. (1956). J. clin. Invest., 35, 842.

Layani, F., Durupt, L., and Amor, B. (1959). Sem. Hôp. Paris, 35, 1282.

Ledlie, E. M., and Baxter, C. F. (1954). In "Radioisotope Conference", 1954: Proc. 2nd Conference, Oxford, vol. 1, p. 97. Butterworth, London.

Mollison, P. L., and Veall, H. (1955). Brit. J. Haemat., $1,62$.

Muldowney, F. P. (1957). Clin. Sci., 16, 163.

Richmond, J., Alexander, W. R. M., Potter, J. L., and Duthie, J. J. R. (1961). Ann. rheum. Dis., 20, 133.

Robinson, W. D. (1963). In "Cecil-Loeb Textbook of Medicine", ed. P. B. Beeson, and W. McDermott, 11th ed, p. 1473. Saunders, Philadelphia.

Ropes, M. W., Bennett, G. A., Cobb, S., Jacox, R., and Jessar, R. A. (1959). Ann. rheum. Dis., 18, 49.

Smith,S.,andMcCabe,E.S.(1948).Ann.intern.Med.,29,445. Weinstein, I. M. (1959). Blood, 14, 950.

\section{L'anémie dans le syndrome de Felty}

\section{RÉSUMÉ}

On étudia le mécanisme de l'anémie dans quatre cas de syndrome de Felty, à l'aide du chrome radioactif $\left.{ }^{(51} \mathrm{Cr}\right)$ pour marquer les globules rouges avant et après la splenectomie. Dans un cas on mesura aussi l'utilisation du fer, à l'aide du fer radioactif $\left({ }^{59} \mathrm{Fe}\right)$ avant et après la splenectomie. On conclut que l'anémie est due surtout à l'hémolyse. On trouva des signes de séquestration splénique augmentée des érythrocytes et chez tous les malades l'anémie fut corrigée par la splenectomie. Les études radioferriques confirmèrent l'utilisation insuffisante du fer pour la synthèse de l'hémoglobine, ce qui ne fut pas amélioré par la splenectomie. L'enlèvement de la rate corrigea la leucopénie présente dans tous les cas et aussi la thrombocytopénie existante chez deux d'entre eux.

\section{La anemia en el sindrome de Felty}

\section{SUMARIO}

Se estudio el mecanismo de la anemia en cuatro casos de sindrome de Felty con el empleo del cromo radioactivo ${ }^{51} \mathrm{Cr}$ ) para marcar eritrocitos antes y después de esplenectomía. En un caso la utilización de hierro fué también medida, sirviéndose de hierro radioactivo $\left({ }^{59} \mathrm{Fe}\right)$ antes y después de esplenectomía. Se concluyó que la anemia se debe principalmente a la hemólisis. Se encontró evidencia de secuestración esplénica aumentada de eritrocitos y en todos los enfermos la anemia fué corregida por la espelenectomía. Los estudios radioferrícos confirman la utilización insuficiente de hierro en la síntesis de hemoglobina, que no mejoró despuès de la esplenectomía. La extirpación del bazo corrigió la leucopenia presente en todos los casos y también la trombocitopenia existente en dos casos. 